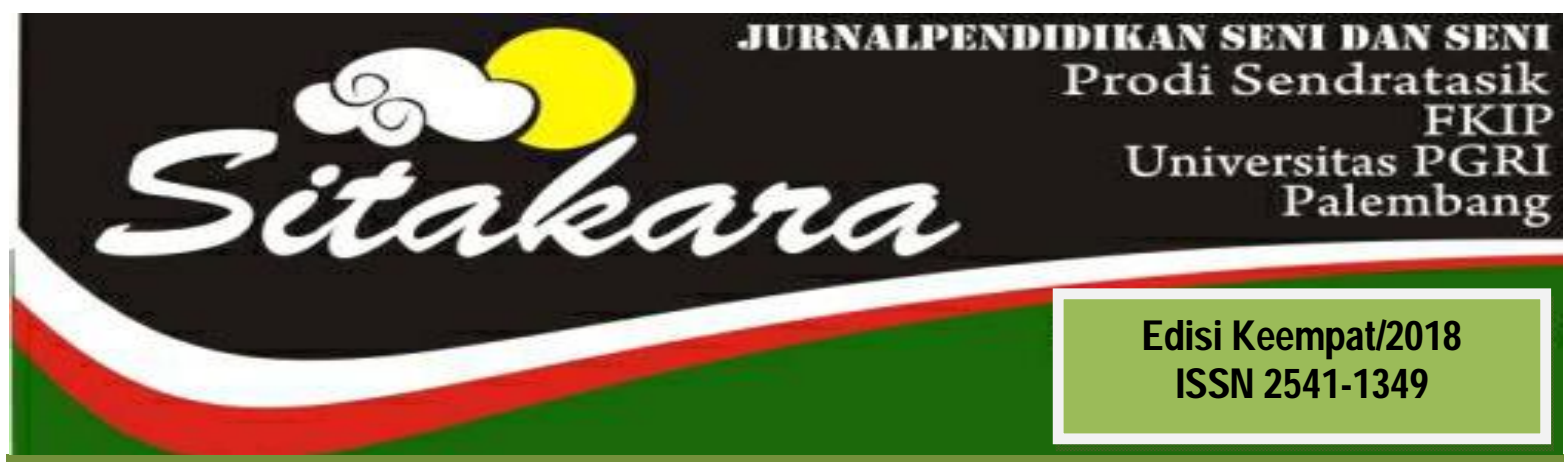

Objektifitas Imajinatif Dalam Pertunjukan Teater

Mohammad A rfani

Makna Estetis Dalam Simbol Tatto

Novdaly Fillamenta

Desain A tas (Air D esign) D alam Dimensi Estetik Pertunjukan Karya Tari

Efita Elvandari

Pengaruh M etode D emonstrasi D alam Pembelajaran Tari Burung Bermain

Pada Kegiatan Ekstrakurikuler D i SM P N egeri 36 Palembang

Ria Moulina A driamul

Gerak: Perjalanan D ari M otif Ke Komposisi Tari

Rully Rochayati

Sastra Lisan Dalam Kesenian Saluang D endang Sumatera Barat

Nofroza Yelli

Rangsang A udio Sebagai M otivasi Pada Penciptaan Karya

Tari Tunggu Tubang Dalam Pembelajaran Koreografi di Universitas

PG RI Palembang

Treny Hera

M otif Bungo Pacik Pada Tenunan Songket Palembang

Mainur

Konsep Kreatifitas Wallas D alam Proses Penciptaan Tari Tepak Keraton

Nurdin

A nalisis Bentuk Gerak Tari Turak Di Sanggar Studio Lingga

Kota Lubuklinggau

Sisca Fitriani

Bentuk Figur Tokoh Wayang Kulit Palembang

Robert Budi Laksana 


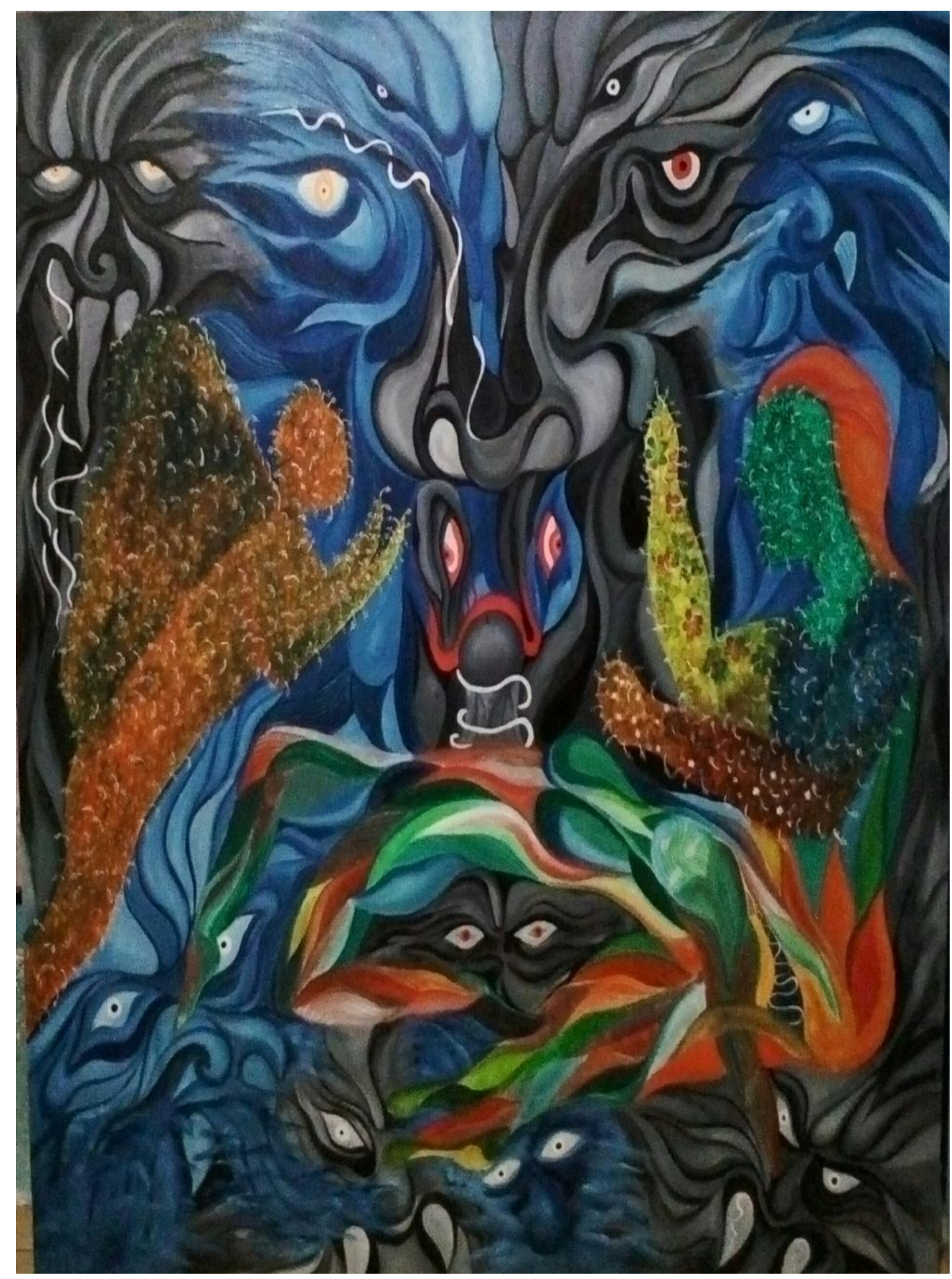




\section{SITAKARA}

\section{JURNAL PENDIDIKAN SENI DAN SENI BUDAYA}

Edisi 4, Februari 2018

\section{DEWAN REDAKSI}

1. PenanggungJawab

2. KetuaDewan Redaksi

3. WakilDewanRedaksi

4. Sekretaris

5. PenyuntingPelaksana

6. Penyunting Ahli

7. Setting
:

: Dra. Andinasari, M.M., M.Pd.

: RullyRochayati, M.Sn

: Nofroza Yelli, M.Sn

: Treny Hera, S.Pd., M.Sn

: 1. Efita Elvandari, M.Sn

2. Arfani, S.Pd., M.Sn

: 1. Prof. Dr. Triyono Bramantyo, P.Hd (ISI Yogyakarta)

2. Dr. DessyWardiah, M.Pd (UPGRI)

3. Dr. Slamet, M.Hum (ISI Surakarta)

4. Yayan Hariyansyah, M.Sn (UIGM)

: 1. Mainur, S.Pd.,M.Sn

2. I Komang Kerta Yana, S.Si

\section{AlamatRedaksi}

Program StudiPendidikanSendratasik JurusanPendidikanKesenian FKIP Universitas PGRI Palembang Jl. A. YaniLorongGotongRoyong 9/10 Ulu Palembang Telp. 0711-510043 Fax. 0711-514782 E-mail: jurnalsitakarasendratasik@yahoo.com 


\section{DAFTAR ISI}

Objektifitas Imajinatif D alam Pertunjukan Teater

M ohammad A rfani

Makna Estetis D alam Simbol Tatto

Novdaly Fillamenta

D esain A tas (Air D esign) D alam D imensi Estetik Pertunjukan Karya Tari

Efita Elvandari

Pengaruh M etode D emonstrasi D alam Pembelajaran Tari Burung Bermain 25 Pada Kegiatan Ekstrakurikuler Di SM P N egeri 36 Palembang

Ria M oulina Adriamul

G erak: Perjalanan D ari M otif Ke Komposisi Tari

Rully Rochayati

SastraL isanD al amK esenianSaluangD endang Sumatera Barat

N ofroza Yelli

Rangsang Audio Sebagai M otivasi Pada Penciptaan Karya

Tari Tunggu Tubang Dalam Pembelajaran Koreografi di Universitas

PG RI Palembang

Treny Hera

Motif Bungo Pacik Pada Tenunan Songket Palembang

Mainur

Konsep K reatifitas Wallas D alam Proses Penciptaan Tari Tepak Keraton N urdin

Analisis Bentuk G erak Tari Turak Di Sanggar Studio Lingga

Kota Lubuklinggau

Sisca Fitriani

BentukFigurT okohWayangKulit Palembang 


\title{
Bentuk Figur Tokoh Wayang Kulit Palembang \\ (Alkulturasi Budaya Jawa-Melayu)
}

Oleh:

\section{Robert Budi Laksana}

(Program Studi Pendidikan Sendratasik FKIP Universitas PGRI Palembang)

\begin{abstract}
Abstrak
Wayang Palembang merupakan nama salah satu jenis wayang kulit purwa yang tumbuh dan hidup di wilayah Kota Palembang. Wayang Palembang diperkirakan ada dan tumbuh pada abad ke XVII, yang dibawa oleh masyarakat Jawa yang migrasi ke Palembang pada masaKeraton Palembang Darusalam.Tentunya wayang Jawa yang mulai hidup di masyarakat Palembangpada masa itu mengalami alkulturasi budaya Jawa dan MelayuPalembang, baik penggunaan bahasa, cerita, iringan maupun rupa wayangnya. Hal itu dapat dilihat dari bantuk anatomi wayang terutama wayang putren (wanita) lebih mendekati gaya Yogyakarta. Karena proses alkultarasi budaya inilah, wayang kulit Palembang memiliki ciri dan keunikan lokalitas tersendiri bila dibandingkan dengan wayang kulit dari Jawa.
\end{abstract}

Kata Kunci: Alkulturasi, Wayang Kulit Palembang

\section{A.PENDAHULUAN}

Kondisi sosial budaya Palembang mempunyai strukturnya sendiri yang jelas dan melewati sejarah yang panjang. Budaya Palembang dibentuk dalam rentang sejarah yang panjang. Kondisi-kondisi yang khas sehubungan dengan lingkungan geografis, kondisi alam, sistem ekonomi dan lingkungan sosial serta pertemuan dengan budaya lain membentuk kebudayaan Palembang, sehingga mempunyai strukturnya sendiri yang khas. Perjuangan wayang purwa yang datang dari Jawa sebagai budaya luar yang berjuang melakukan penetrasi budaya hanya mampu menembus kulit luarnya saja.

Pada budaya wayang initidak terjadi proses akulturasi budaya yang pekat apalagi terjadi asimilasi budaya. Seni Pedalangan Wayang Purwa tidak bisa mengakar pada kebudayaan Palembang. Masyarakat pendukung budaya itu hanya sebatas komunitas keluarga dekat dari leluhur dalang Palembang dari generasi ke generasi. Kalaupun terjadi akulturasi hanya selapis tipis pada salah satu unsur kebudayaan, yaitu pemakaian bahasa Palembang, penyesuaian beberapa tokoh wayang dan dalam pagelaran wayang Palembang (Robert, 2013: 5).

Perbedaan pandangan dan falsafah hidup yang berbeda adalah faktor yang menjadi kendala utama. Budaya Palembang bersifat materialistik, sehingga sulit untuk menanamkan nilai. Konsekuensinya adalah menganggap falsafah hidup dan nilai moral adalah faktor ikutan belaka. Yang bersifat sentral dan menentukan dalam kehidupan manusia. Sebaliknya yang menjadi sendi utama dalam kehidupan masyarakat adalah lokak- 
lemak (materi dan kenikmatan) yang bisa dirasakan kegunaannya secara langsung secara ekonomis dan praktis (Robert, 2012: 50).

Sedangkan budaya Jawa lebih sebagai budaya yang bersifat idealistik. Dalam pandangan ini, inti budaya bukanlah hal yang konkret, melainkan ide dan lambang sebagai inti dari kebudayaan. Sistem gagasan yang berbeda inilah yang menjadikan wayang tidak bisa berkembang di Palembang. Tidak ada sumber sejarah yang otentik mencantumkan data-data sejarah mengenai pertumbuhan dan perkembangan Wayang Palembang. Yang ada hanyalah bersumber dari tradisi tutur yang diwariskan dari generasi ke generasi, terutama dari keluarga dalang Wayang Palembang yang sampai sekarang tetap melestarikan tradisi Wayang Palembang yaitu Sanggar Sri Palembang yang berada di Kelurahan Tangga Buntung.Penelitian ini dilakukan di wilayah Kelurahan Tangga Buntung, dimana disana terdapat satu-satunya sanggar seni wayang kulit Palembang yang masih eksis sampai sekarang.Penelitian ini ditujukan untuk mengetahui bagaimana bentuk alkulturasi budaya Jawa-Melayu pada bentuk figur tokoh wayang Palembang.

Ditinjau dari bentuk rupa wayangnya tidak dipungkiri bahwa wayang Palembang berasal dari Jawa. Dari gaya wayang putren (wanita) juga dari rupa ornamen, bisa dipastikan wayang Palembang berasal dari Jawa gaya Yogyakarta. Hal ini dilihat dari wayang yang paling tua yang ada di Sanggar
Sri Palembang, jelas bahwa wayang tersebut berasal dari Jawa. Sedangkan wayang-wayang srambahan 'tokoh-tokoh pelengkap' dibuat di Palembang. Kemudian wayang-wayang yang paling baru adalah wayang-wayang yang dibuat oleh pengrajin wayang gaya Surakarta dan juga Yogyakarta (wawancara dengan Wirawan, 2017).

Di dalam perjalanannya yang panjang semenjak memasuki wilayah Sumatera, wayang Palembang tentunya bersentuhan dan mengalami benturan dengan budaya setempat, mengadopsi unsur-unsur budaya setempat, terutama adalah penggunaan bahasa Palembang dalam narasi maupun dialog untuk dapat bertahan hidup. Secara umum sumber ceriteranya adalah Mahabharata, dan juga Ramayana, namun mengalami pengolahan cerita berupa garap sanggit sebagai lakon carangan cerita lokal yang khas. Hal ini lah yang menjadi latar belakang tulisan ini, dimana keberadaan wayang kulit Palembang adalah suatu artefak budaya yang unik dan menjadi indentitas lokal masyarakat Palembang terutama dalam bentuk figur tokohnya sehingga dapat dijadikan suatu kajian yang menarik.

\section{METODE PENELITIAN}

Metode yang digunakan pada penelitian ini adalah metode kualitatif dengan pendekatan multidisplin antaralain sejarah, sosiologi dan juga estetika. 


\section{E. PEMBAHASAN}

\section{Bentuk Figur Tokoh Wayang Kulit Palembang}

\section{Keberadaan Wayang Kulit Palembang}

Kata wayang (bahasa Jawa) bervariasi dengan kata "bayang", yang berarti bayangan. G.A.J Hazeu mengatakan bahwa wayang dalam bahasa/kata Jawa berarti bayangan, yang dalam bahasa Melayu "bayang-bayang" yang artinya bayangan/ samar-samar, menerawang (Hazeu, 1979). Wayang pertama kali adalah mengambil dari cerita sebuah ukiran pada relief candi-candi yang menggambarkan tokoh para leluhur, legenda kepala suku. Wayang merupakan kesenian tradisional yang telah ada sejak beberapa abad yang lalu yaitu sejak zaman prasejarah, yang kemudian berkembang sesuai zamannya dengan mengambil cerita Ramayana dan mahabarata yang berasal dari India dan kemudian diadopsi oleh masyarakat Jawa. Wayang kulit adalah bayangan yang merujuk pada boneka dari kulit binatang (berlulang; kerbau atau sapi), pipih, dipahat, diwarnai bertangkai (Soetarno, 2010:1).

Masyarakat Indonesia pada masa sejarah telah memiliki kepercayaan animisme berupa pemujaan roh nenek moyang yang disebut dengan hyang atau dahyang, yang diwujudkan arca atau gambar. Dalam perkembangannya wayang dibagi dalam beberapa periode sesuai dengan jiwa zamannya.Keberadaan Wayang Indonesia untuk mendapatkan pengakuan dari UNESCO melewati perjalanan yang sangat panjang. Ketika Kementerian Kebudayaan dan Pariwisata melalui Deputi Bidang Seni dan Film tahun 2002 menugaskan Senawangi untuk mempersiapkan pencalonan wayang Indonesia sebagai karya agung budaya tak benda. Senawangi segera membentuk tim riset untuk mengadakan penelitian terhadap wayang Indonesia. Dari ratusan jenis wayang yang ada, Senawangi memilih 5 jenis wayang mewakili wayang Indonesia yakni, wayang kulit purwa dari Jawa Tengah, wayang Bali, wayang Golek Purwa, wayang Banjar dari Kalimatan Selatan dan wayang Palembang dari Sumatera Selatan (Senowangi, 2000).

Wayang Palembang adalah nama salah satu jenis wayang kulit purwa yang tumbuh dan hidup di wilayah Kota Palembang. Kesenian wayang Palembang saat ini keberadaannya masih eksis walaupun hanya terdapat satu kelompok kesenian wayang kulit Palembang di wilayah Sumatera Selatan. Tidak ada sumber sejarah yang otentik mencantumkan data-data sejarah mengenai asal-usul wayang Palembang. Sumber yang ada hanyalah dari tradisi tutur (oral history) yang diwariskan dari generasi ke generasi, terutama pada keluarga dalang wayang Palembang itu sendiri. Namun apabila dilihat dari bentuk rupa wayang tidak dipungkiri bahwa wayang palembang berasal dari Pulau Jawa. menurut penelitian yang dilakukan oleh Sulebar dan Mikka Wilda tahun 2002, menyimpulkan bahwa masuknya Jawa ke Palembang pada abad ke XVII, yang dibawa oleh masyarakat Jawa yang migrasi ke Palembang (wawancara dengan Wirawan, 2017).

Bila dilihat dari bantuk anatomi wayang putren (wanita) lebih mendekati gaya Yogyakarta dibandingkan dengan Surakarta. Sementara itu keraton Yogyakarta berdiri pada tahun 1755 pecahan dari Keraton Kasunanan Surakarta dengan Raja Sri Sultan Hamengku Buwono I (hasil perjanjian Giyanti 1755). Sejak saat itulah lahir wayang gaya/gagrak Yogyakarta. Dengan berdirinya pemerintahan dan tata wilayah baru 
tersebut dirasakan perlu suatu bentuk kesenian dan budaya baru serta nilai-nilai tersendiri sebagai identitasnya. Mengacu pada penjelasan tersebut, bila dilihat secara rinci bentuk tokoh wayang Palembang lebih condong ke gagrak Yogyakarta dibandingkan Surakarta. Hal ini kemungkinan disebabkan adanya migrasi pada masa tersebut orang-orang Jawa dan membawa seni pewayangan di kota Palembang.

\section{Bentuk Figur Tokoh Wayang Palembang}

Boneka wayang Palembang pada dasarnya hampir mirip dengan perwujudan wayang kulit purwa gaya Yogyakarta. Yang membedakan dengan wayang purwa gaya Yogyakarta dengan wayang kulit gaya Palembang adalah terletak di pewarnaan wayangnya. Dalam mengenali wayang kulit Palembang kita harus mengenali ciri-ciri sebagai berikut; (a) Pada dasarnya wayang kulit Palembang menggambarkan tokoh wayang bergerak (berjalan), hal ini ditandai dengan posisi kaki yang melangkah lebar terutama pada tokoh gagahan. Pada posisi belakang digambarkan ddengan posisi telapak kakina miring atau jinjit. Tapilan yang demikianlah lebih gagah, ekspresi dan dinamis. Ooh putrinya dalam wayang Palembang menggambarkan wayang diam/berheti/ tidak bergerak, hal ini ditandaai dengan adanya wiron nyamping (lipaatan-lipatan kain kampuh) yang tetap ada diposisi muka. (b) Pada tokoh satrya (Bima, gatokaaca) cenderung tapilan bentuk badan atau tubuh terlihat pendek, kekar (gemuk), bagian kepala tampak lebih besar, posisi tubuh menghadap kemuka, dengan posisi kaki terbuka lebar. Kaki digambarkan tampak lebih pendek dari seharusnyaa.Proporsi bagian kepala, tubuh, kaki dan tangan yang demikian ini memberikan kesan cebol. (c) Pada umumnya tokoh-tokoh dalam wayang kulit gaya Palembang mempunyai tangan yang panjang hingga menyentuh kaki. Hal ini berkaitan dengan fungsi wayang itu dalam pagelaran.Dalam kegiatan menyembah membutuhkan tangan yang mampu menyentuh hidung dari tokoh wayang tersebut, sehingga dibutuhkan ukuran yang panjang.Hal ini juga merupakan bentuk ukuran bahwa tubuh hingga kaki tokoh wayang sebanding ukuranya dengan panjangnnya tangan tokoh wayang itu. Perlu kita ketahui bahwa wayang kulit gaya Palembang digambarkan dengan bahu belakang panjang. (d) Muka dalam wayang kulit gaya Palembang menghadap ke depan, terlihat dari samping (separuh), dan cenderung menghadap ke bawah (merunduk), berwarna hitam, merah muda, biru muda, dan emas (gembleng). (e) Pada tokoh satria gagah seperti Gatotkaca dan Antareja mata terlihat melotot telengan (bahasa Jawa) dan diwarnai puth untuk dasarnya, ditambahkan merah dan hitam pada tengahnya. (f) Pada tokoh-tokoh satria yang berbadan kecil seperti Janaka, Rama, Kresna), pundaknya terlihat lebih pendek pada bagian belakang. (g) Pada bagian tengah antara tangan dan kaki depan dan belakang (pelemahan), umumnya diberi warna merah (wawancara dengan Wirawan, 2017).

Berdasarkan penjelasan di atas jelas sekalai jika kita telaah lebih jauh lagi, wayang kulit Palembang memiliki keunikan tersendiri dibandingkan dengan bentuk wayang gaya Yogyakarta maupun Surakarta. $\mathrm{Hal}$ ini dimungkinkan karena hubungan kedua kerajaan pada masa Keraton Yogyakarta dan Keraton Palembang Darusalam. Kesenian wayang kulit gaya Palembangan ini sudah memasukan ajaran agama Islam sebagai materi pementasanny 


\subsection{Bentuk Tokoh Pewayangan Dewa}

\section{a. Batara Guru}

Batara Guru adalah Putra sang Hyang Tunggal dengan istrinya yang bernama Dewi Wirandi putri jim. Batara Guru termasuk dalam wayang morgan yang tergolong istimewa, dengan karakter luruh, posisi muka tumungkul dengan hiasan turida, jamang, sumping mangkara, uncit bermotif bludiran dengan kancing gelung gelapan utah-utah pendek dan memakai rembing. la duduk di balai marcupunda yang bentuknya mirip dengan praba dan berdiri diatas lembu Andini. Tokoh ini bertangan empat dengan mengenakan kelat bahu naga pangangrang, gelang calumpringan dan memakai keroncong.

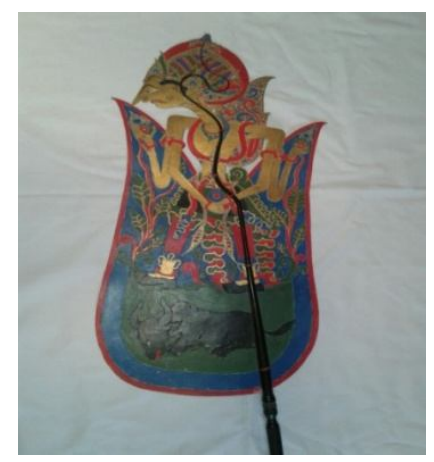

Gambar 1. Tokoh Bethara Guru Wayang Palembang

(Dok.Wirawan, Foto: Retno, 2017)

\section{b. Dewa Narada}

Narada pada masa mudanya bernama Manan, yang merupakan putra Sang Hyang Tunggal yang tercipta dari sebuah telur yang bercahaya. la dinamakan pula kanekaputra, sebutan Narada karena bentuknya cebol kepalang. Posisi muka langak, dengan mata modifikasi dari jenis kleden, hidung wungkal gerang, mulut gusen dengan kumis, jenggot dan jambang yang lebat, ia memakai mahkota uncit dengan dengan motif bludiran , sumping mangkara dan memakai rembing. Badan ngropoh menganakan sampir bermotif bludiran, posisi kaki pocong blotrong dengan dodot bermotif parang.

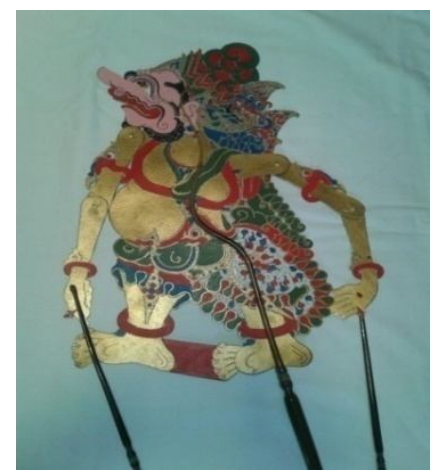

Gambar 2.Tokoh Dewa Narada Wayang Palembang

(Dok.Wirawan, Foto: Retno, 2017) 


\subsection{Bentuk Tokoh Pewayang Pendita/Resi}

\section{a. Pendito Abiyasa}

Abiyasa adalah putra bagawan Palasara dari pertapaan Wukiratawu dengan istri Dewi Setyawati, yang kemudian diperistri Santanu dari negara Astina. Abiyasa termasuk tokoh pandita dengan karakter luhur, dengan posisi muka tumungkul, bermata liyepan yang telah dimodifikasi menjadi bentuk mata khusus orang tua dengan kulit yang sudah keriput, berhidung lancip (walimiring), dan mulut salitan dengan penggambaran tanpa gigi. la bermahkota puttut (ubel-ubelan) dengan hiasan sumping mangkara, nyamat, dan memakai rembing. Tubuh melengkung kedepan dengan mengenakan jubah. la menyandang keris dengan hulunya untuk menggantung tasbih, memakai kain panjang dengan motif parang rusak dan tidak memakai sepatu. Tangan kanan dibuat irasan dengan memegangi senjata Trisula.

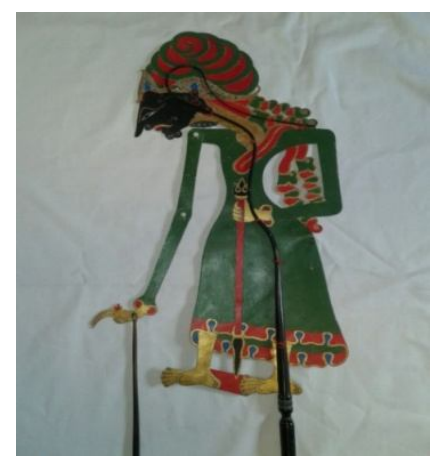

Gambar 3.Tokoh Pendita Abiyasa Wayang Palembang

(Dok.Wirawan, Foto: Retno, 2017)

\section{b. Pendito Durna}

Pendito durna adalah putra resi baramadya dari hargajemangan dengan istrinya yang bernama dewi kumbini. Durna memiliki posisi muka langak, bermata penanggalan (kiyeran) dengan hidung wunngkal gerang dengan posisi terbalik dengan mulut gusemberkumis dan bercambang tipis. Rambut digulung gondel dan diikat dengan tali bersumping mangkara. Tubuh memakai baju dengan motif tumbuh-tumbuhan dengan sampir dan jubahh, dengan jangkahan panditan.

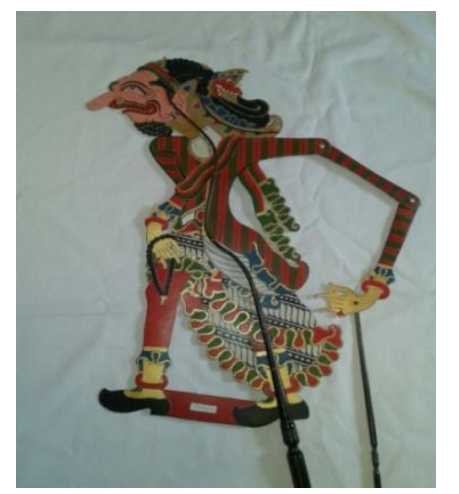

Gambar 4.Tokoh Pendita Dhorna Wayang Palembang

(Dok.Wirawan, Foto: Retno, 2017) 


\subsection{Pewayangan Gagahan}

\section{a. Werkudoro}

Werkudoro adalah salah satu Pandawa, ia adalah putra Prabu Pandudewanata dengan Dewi Kuntinalibranata.Werkudara berpenampilan luruh, bermata thelengan, hidung bentulan, dan bermulut salitan engan kumis, jenggot dan cambang yang amat tebal. la bermahkota gelung supit urang jenis minangkara, bersumping pandang binethot, dengan memakai pupuk mjarot asem dan anting-anting bayu. Tubuh gagahan alus, dengan simbarjaja dan gagah gelar dengan jangkahan sena. Pada bagian kaki digambari kepala nagaraja dengan konca bayu. Atribut yang lain adalah kuku pancanaka, kelat bahu dan gelang candrakirana.werkudara ditampilkan dengan muka hitam badan badan gembleng.

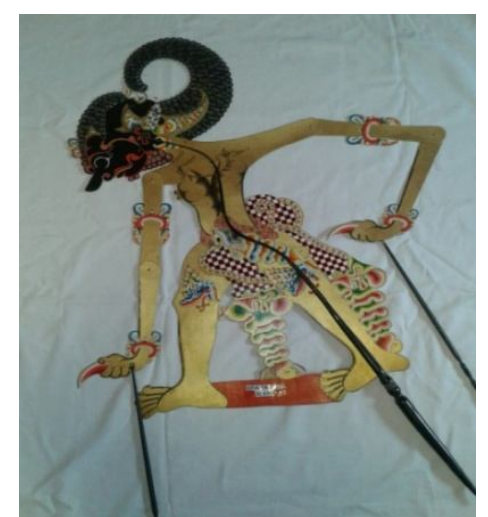

\section{Gambar 5.Tokoh Werkudara Wayang Palembang}

(Dok.Wirawan, Foto: Retno, 2017)

\section{b. Gatutkaca}

Gatutkaco adalah putra arya Werkundara salah satu pandawa dengan istrinya dewi arimbi putri raja pringgadani. Posisi kaki dinamakan jangkuhan raton dengan dua pasang uncul kencana, sepasang uncul wastra,clana cide puspita,dengan dodot bermotif perang barang. Atribut yang lain memakai kelatbahu naga pangangrang,gelung columpringan dan memakai keroncong. Gatutkaca ditampilkan dengan muka hitam dalam gembleng, dalam wanda tertentu dengan muka dan badan gembleng dan dengan muka dan tubuh diwarna hitam .wanda gentur (dhukun),kilat(panglawarang), tathit.

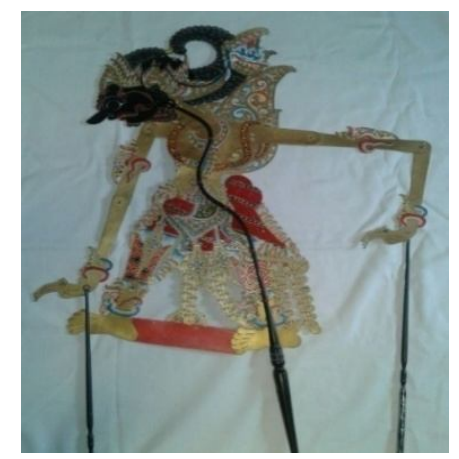

Gambar 6.Tokoh Gatutkaca Wayang Palembang

(Dok.Wirawan, Foto: Retno, 2017) 


\section{c. Prabu Duryudana}

Duryudana adalah raja Negara astina,ia putra prabu destrarastra raja Negara gajagoya dengan permaisurinya yang bernama dewi gendari. Rambut ngere odol,dengan menggenakan praba sebagai simbol dari kebesarannya sebagai raja. Badan gagahan memiliki ulur-ulur naga mamongsa tali praba dengan motif bludiran. Posisi kaki dengan pocong banyakan lis sembuliyan, dengan dodot perang rusak seling gurda ada sepasang uncal kencana yang menyetainya.

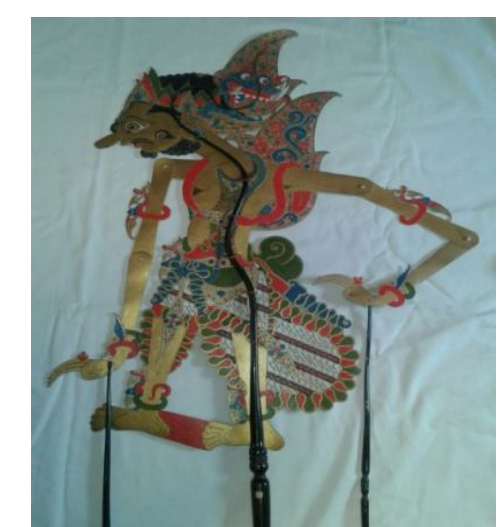

Gambar 7.Tokoh Duryudana Wayang Palembang

(Dok.Wirawan, Foto: Retno, 2017)

\section{d. Dursasana}

Tokoh ini memiliki perwatakan suka berbuat sewenang-wenang, dan takaburDursasana tergolong dalam wayang gagahan dengan karakter brasak atau kasar, dengan posisi muka langak. la bermata plelengan, berhidung wungkel gerang, bermulut gusen dengan kumis, jenggot dan jambang tebal. la bermakohta trumbos dengan hiasan turida, jamangsusun, sumping soreng pati dan gelapan dan utah-utah pendek, serta memakai rembing. Badan gagahan dengan memakau ulur-ulur naga memongsa, dengan jangkahan rotan.

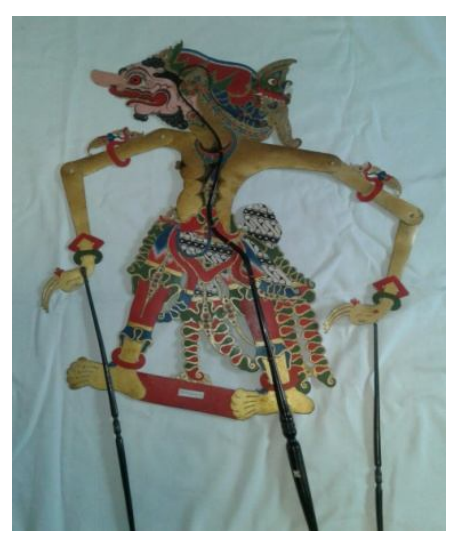

Gambar 8.Tokoh Dursasana Wayang Palembang

(Dok.Wirawan, Foto: Retno, 2017) 


\section{4. Pewayangan Satria}

\section{a. Puntodewo}

Puntadewo adalah salah satu pandawa lima yang paling tua dan menjadi raja amarta. Puntadewa berpenampilan luruh, posisi muka tumungkul, bermata liyepan, berhidung walimiring. Bermulut salitan, ia mengenakan mahkota gelung keling, memakai sumping prabanagyun, badan satria alus dengan hiasan gajahgelar, posisi kaki pocong banyakan dengan motif semen ningrat untuk tepian dodot dengan motif semen jrengut seling gurda.

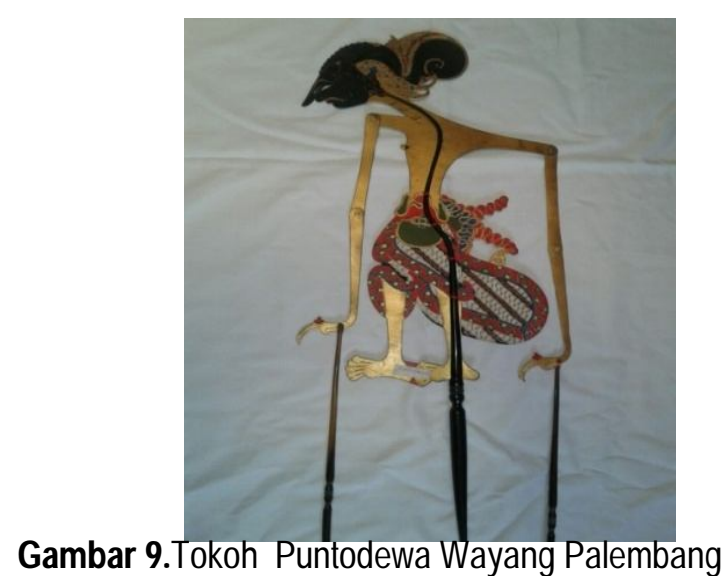

(Dok.Wirawan, Foto: Retno, 2017)

\section{b. Bambang Tuseno}

Bambang Tuseno merupakan Wayang tambahan dalam cerita di wayang Palembang. Bambang Tuseno ini termasuk kelompok tokoh alusan, dengan posisi muka luruh, bermata liyepan, berhidung walimiring, bermulut salitan. la bermahkota gelung supiturang bersumping waderan (kuduk turi) dan memakai rembing. Badan satria alus dengan hiasan gajah gelar pada bagian dadanya. Posisi kaki jangkahan satria putran dengan dodot berbentuk kawung.

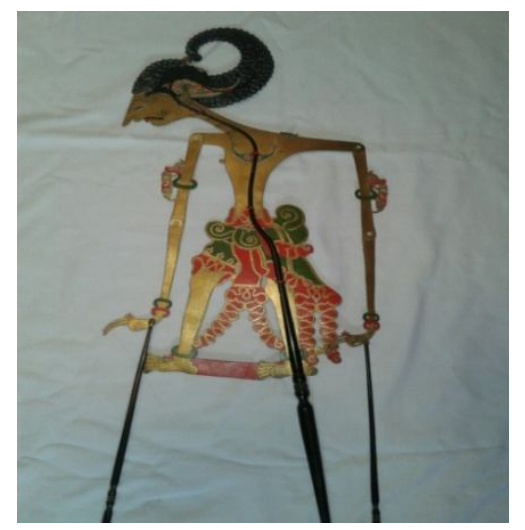

Gambar 10.Tokoh Bambang Tuseno Wayang Palembang

(Dok.Wirawan, Foto: Retno, 2017 


\section{c. Bambang Darmojati / Pancawala}

Pancawala adalah satria pandawa yang seusia raden Abimanyu, ia sangat akrab dengan saudaranya raden Antasena. Pancawala termasuk ke dalam tokoh jangkahan yang berkarakter luruh dengan posisi muka tumungkul, bermata liyepan berhidung walimiring, dan bermulut salitan. la mengenakan mahkota gelung keling dengan hiasan turida jamang, sumping mangkura, dan memakai rembing. Badan alusan dengan hiasan kalung tanggalan.

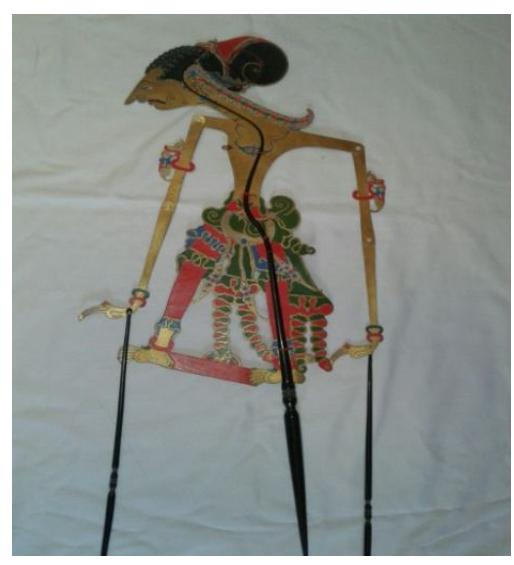

Gambar 11.Tokoh Bambang Darmojati Wayang Palembang

(Dok.Wirawan, Foto: Retno, 2017)

\section{d. Raden Arjuno}

Arjuna adalah putra pandudewanata dengan dewi kunti. Arjuna berpenampilan posisi muka tumungkul, bermata liyepan, berhidung walimiring, dan bermulut salitan. Mahkota dengan gelung minangkara, dengan sumping waderan, tubuh satria alus dengan penggambaran gajah gelar. Bagian bawah dengan pemakaian kain dalam pocong polos, dengan motif sekar jeruk dengan manggaran berada dibelakangnya. Arjuna berpenampilan alusan bahkan tanpa atribut. Tangan tanda kelatbahu dan tanpa gelang.

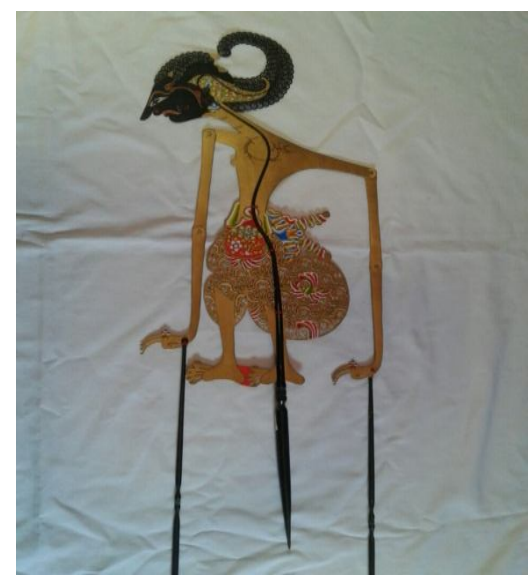

Gambar 12.Tokoh Arjuno Wayang Palembang

(Dok.Wirawan, Foto: Retno, 2017) 


\section{e. Sri Rama}

Rama adalah putra prabu Dasarata dengan permaisyurinya bernama dewi Mulyandari yang berkedudukan di Madyapura.Rama berpenampilan luruh dengan posisi muka tumungkul, bermata liyepan, berhidung walimiring, dan bermulut salitan. la menggunakan mahkota makuta, dengan hiasan berupa turida, jamang susun tiga, jungkat penatas, kalawista, nyamat, gelapan utah-utah pendek dan menggunakan sumping mangkara. la mengenakan praba sebagai simbol kekuasaanya sebagai seorang raja, mengenakan sampir, ulur-ulur naga mamongsa, kelat bahu naga pangangrang, gelang calumpringan,dan menggunakan keroncong. Mengenakan sepasang uncal kencana.

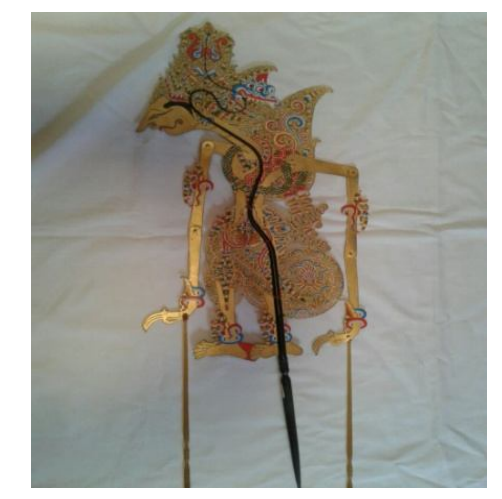

Gambar 13.Tokoh Sri Rama Wayang Palembang

(Dok.Wirawan, Foto: Retno, 2017)

\subsection{Pewayangan Raksasa}

\section{a. Rahwana}

Rahwana adalah nama lain dari dasmuka sebelum menjadi raja besar di Negara alengka. Rahwana berwajah bengis dan kejam,bermata plelengan,berhidung wungkal Gerang.bermulut gusen,dengan kumis,jenggot dan cambang yang lebat. la bermahkota pogag,dengan hiasan turida,amang rangkap dua, sumping mangkara,dengan gelapan Utah-utah walik.rambut gimbal ngore,memakai praba sebagai simbol kedudukan sebagai raja, badan gagahan ageng,dengan ulur-ulur naga mangsa,tali praba dengan motif geomertrik.

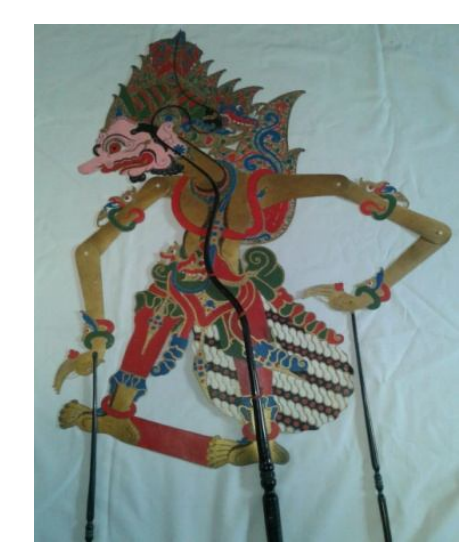

Gambar 14.Tokoh Rahwana Wayang Palembang

(Dok.Wirawan, Foto: Retno, 2017) 


\section{b. Kumbakarna}

Kumbakarna adalah raksasa berukuran besar dengan mata plelegan,hidung pelokan,mulut ngablak dengan kumis,jenggot dan cambang yang sangat lebar. la memakai makhota makuta dengan hiasan turida,jamang susun tiga,jungkat piñatas,karawista,dawala,nyamat bersumping mengkara dan kancingngnya gelapan Utah-utah pendek. Posisi kaki jangkaan denawaratonl dan dengan dua pasang muncul kencana,sepanjang uncal wastra,e;ana cinde puspista dan dodol bermotif parang rusak.

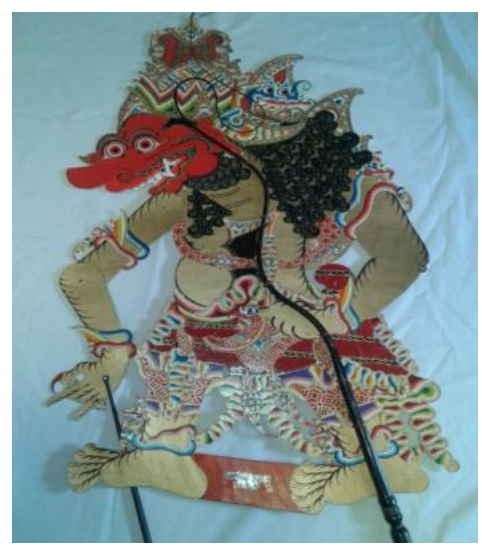

Gambar 15.Tokoh Kumbakarna Wayang Palembang

(Dok.Wirawan, Foto: Retno, 2017)

\subsection{Pewayangan Punakawan}

a. Semar

Semar berpenampilan selalu serius, bermata rembesan, berhidung sunthi bermulut cablek dengan tubuh ngropoh (gemuk dan pendek). Tangan mengenakan gelang dagelan dengan jari-jari ngepel dan nuding. Atribut lainnya memakai anting-anting lombok abang, posisi kaki pocong dagelan dengan motif poleng, dengan warna merah, hitam dan putih (umumnya motif ini dibuat seragam dengan pundakawan lainya).

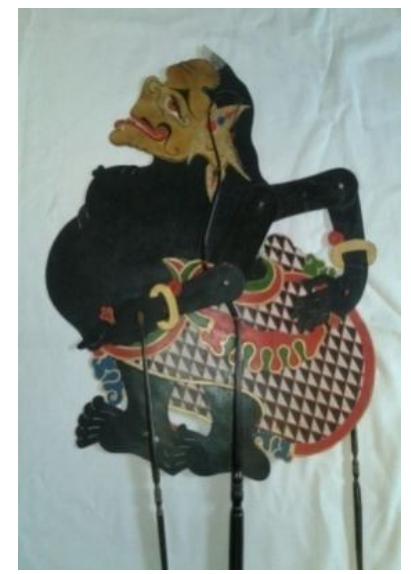

Gambar 16.Tokoh Semar Wayang Palembang 
b. Petruk

Pertuk tampil dengan santai dan rileks, bermata kedelen yang telah dimodifikasi, berhidumh dewa, mulut mesem, tubuh ngropoj dewa, dengan pocong dagelan yang bermoitf slobok atau kambil sekucil. Atribut yang lain memakai kalung gentha, meyadangkan pethel, memakai gelang dagelan lain memakai kalung gentha, menyadangkan pethhel, memakai sepatu. Tokoh ini selalu bermuka senang dan gembira putih dengan badan gambleng. Wanda: jamlang, jlegong dan bujang.

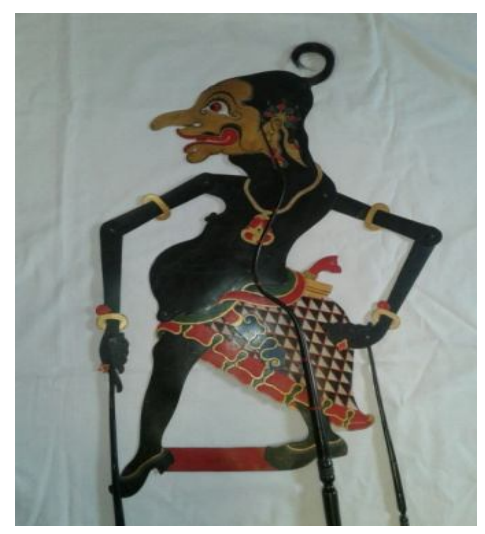

\section{Gambar 17.Tokoh Petruk Wayang Palembang}

(Dok.Wirawan, Foto: Retno, 2017)

c. Gareng

Nala Gareng berpenampilan lucu, bermata keran, berhidung nerok glatik, bermulut mesem, berkucir. Tubuhnya ngropoh, dengan posisi kaki dengan pocongdagelan dengan motif kambil secukil. Atribut lainnya tangan ceko dengan jari-jari nuding dan megar, kaki kanan gejig, memakai kalung duit, dan gelang dagelan

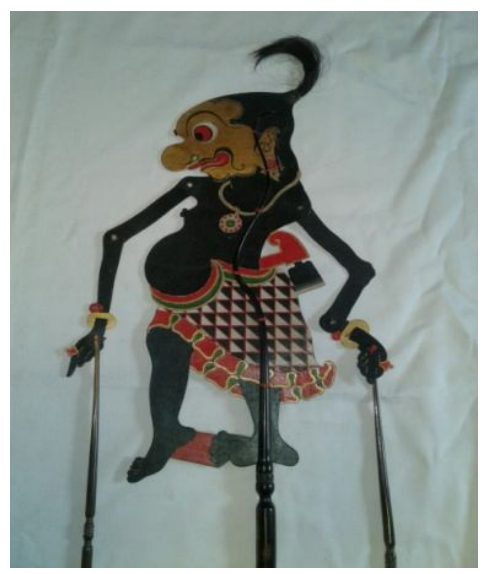

Gambar 18.Tokoh Gareng Wayang Palembang

(Dok.Wirawan, Foto: Retno, 2017) 


\subsection{Pewayangan Putri}

a. Dewi Arimbi

.Arimbi tergolong dalam wayang morga, termasuk dalam golongan putren luruh, dengan posisi muka tumungkul, mata plelengan, hidung wungkal gerang dengan mulut ngablak dengan gigi dan taring yang runcing. la memakai mahkota popag dengan hiasan jamang sadaseler, jamang, sumping mangkara, dengan gelapan utah-utah pendek. Badan putren dengan rimong bermotif bludirandengan semekan, pinjong dengan motif semen jrengut seling gurda. Kain panjang bermotif klitik. la memakai kelatbahu naga panganggrang, gelang calumpringan dan memakai binggel. Sebagai kelang kaki, tangan Arimbi digambarkan sebagai tangan raseksi. Tokoh ini ditampilkan dengan muka putih dengan badan gembleng.

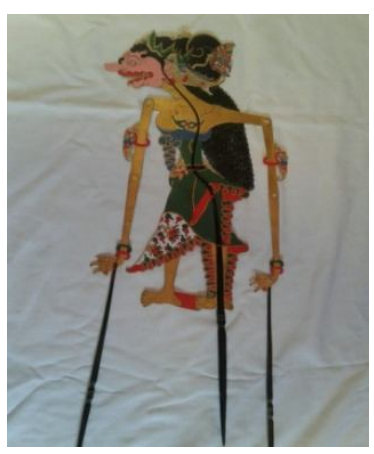

Gambar 19.Tokoh Dewi Arimbi Wayang Palembang

(Dok.Wirawan, Foto: Retno, 2017)

\section{b. Dewi Sinta}

Dewi Sinta ditampilkan sebagai sosok wanita yang bertabiat halus, dengan posisi muka luruh, bernama liyepan, berhidung lancip (walimiring) dan bermulut salitan. Ada penggambaran sinom yang terurai di dahinya, dengan mahkota gundulan berhias Jamang Sadaseler, sumping mangara dengan cunduk bintulu (gelapan alit). Rambut ngore gendong, badan putren dengam sampir bermotif kembangan. la menggunakan kelatbahu naga panganggrang, gelang calumpringan, binggel sebagai gelang kaki. Putren ini ditampilkan dengan muka dan badan gemblaeng. Wanda : Rangkung, sedet,dan Padasih.

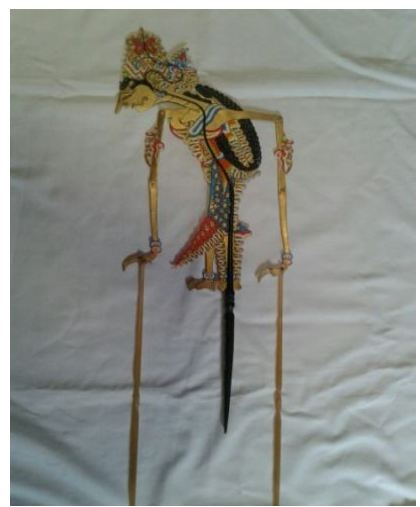

Gambar 19.Tokoh Dewi Shinta Wayang Palembang (Dok.Wirawan, Foto: Retno, 2017) 


\section{SIMPULAN}

Berdasarkanbentuk dan jenisnya tokoh pewayangan Palembang terbagi atasPe-Wayangan Dewa, yang membedakannya dengan pewayangan lain adalah cirikhas terlihat di sepatunya. Pewayangan Gagahan, yang membedakannya dengan pewayangan lain adalah cirikhas terlihat di bentuk tubuh yang tinggi dan bahu yang terlihat kokoh. Pewayangan Satria, yang membedakannya dengan pewayangan lain adalah cirikhas terlihat pada bentuk tubuh yang ramping dengan bahu yang gagah namun sedikit kecil jika dibandingkan dengan pewayangan gagahan.Pewayangan punakawan, perbedaannya sangat terlihat jelas, dengan keadaan fisik yang lucu. Dalam wayang Palembang tokoh pewayangan punakawannya tidak memiliki bagong. Yang ada hanya Semar, Petruk, dan Gareng. Pewayangan Pendita berpenampilan sederhana dan menjadi pembimbing untuk beberapa tokoh.Pewayangan putri, sudah terlihat jelas bahwasanya putri adalah wanita, jadi pewayangan yang berparas wanita semuanya tergolong pewayangan putri. Dari bentuk figure penokohan wayang kulit Palembang ini sangat jelas terlihat adanya alkulturasi budaya Jawa dan Melayu dalam perwujudan wayangnya. Wayang Palembang bila dilihat lebih rinci bentuknya agak kecil bila dibandingkan dengan wayang dari Jawa. Pewarnaan dan asesoris yang digunakannya pun mengalami perubahan warna yang condong gaya Palembangan menggunakan warna merah, biru, dan emas.

\section{Daftar Pustaka}

Budi Laksana, Robert.2013. Pengantar Kebudayaan Sumatera Selatan. Palembang: Universitas PGRI Palembang.

2012.Pengantar Pengetahuan Pewayangan. Palembang: Universitas PGRI Palembang.

Dharsono (Sony Kartika). 2007. Estetika. Bandung: Rekayasa Sains.

Hazeu, G.A.J. 1979. Kaweruh Asalipun Ringgit Sarta Gegepokanipun Kaliyan Agama Ing Jaman Kina. Jakarta: Departemen Pendidikan dan Kebudayaan Proyek Penerbitan Buku Bacaan dan Sastra Indonesia dan Daerah.

M.Jazuli.2014.Sosiologi Seni: Pengantar dan Model Studi Seni Edisi 2. Yogyakarta: Graha Ilmu.

Kayam, Umar.2001. Kelir Tanpa Batas. Yogyakarta: Gama Media, Pusat Studi Kebudayaan UGM, dan The Toyota Foundation.

Senowangi.2000. Ensiklopedia Wayang Indonesia. Jakarta: Sekretarian Nasional Wayang Indonesia.

Sunarto dan Sagio, 2004. Wayang Kulit Gaya Yogyakarta Bentuk dan Ceritanya. Program Pengadaan Barang Bercorak Kebudayaan Kesenian.

Suseno, Franz Manis.1991. Wayang dan Panggilan Manusia. Jakarta: Gramedia Pustaka Utama.

Soetarno.2010. Teater Wayang Asia. Surakarta: ISI Press. 


\section{KETENTUAN PENULISAN ARTIKEL JURNAL SITAKARA}

1. Naskah berbahasa Indonesia bertemakan Seni Budaya yang meliputi hasil penelitian pengajaran seni budaya, cabang seni, dan kebudayaan.

2. Naskah harus asli dan belum pernah dimuat dalam media lain. Naskah dapat berupa hasil penelitian perorangan atau kelompok. Naskah ditulis dengan cara-cara yang sesuai dengan ketentuan penulisan artikel ilmiah menggunakan bahasa Indonesia yang baku, berupa ketikan, beserta soft line dalam CD-RW atau dengan mengirimkan email pada redaksi Jurnal Sitakara dengan alamat email: jurnalsitakarasendratasik@yahoo.com, spasi 1,5 jenis huruf Arrial Narrow ukuran 12, dengan panjang naskah antara 8-15 halaman pada kertas A4.

3. Artikel hasil penelitian memuat:

JUDUL

NAMA PENULIS

ABSTRAK

\section{A. PENDAHULUAN}

B. METODE PENELITIAN

C. HASIL DAN PEMBAHASAN

D. SIMPULAN

4. Artikel kajian konseptual memuat JUDUL

NAMA PENULIS

ABSTRAK

PENDAHULUAN

SUB JUDUL

SIMPULAN

DAFTAR PUSTAKA

\section{: XXX (HURUF KAPITAL)}

: (disertai jabatan dan institusi)

: (Bahasa Indonesia yang memuat 100- 150 kata diikuti kata kunci, dengan jenis huruf Arrial Narrow dan ukuran huruf 11 serta dicetak tebal).

: (Memuat latar belakang masalah, tinjauan pustaka Secara ringkas, masalah dan tujuan penelitian).

: (Berisi simpulan)

: XXX (HURUF KAPITAL)

: (disertai jabatan dan institusi)

: (Bahasa Indonesia yang memuat 100- 150 kata diikuti kata kunci, dengan jenis huruf Arrial Narrow dan ukuran huruf 11 serta dicetak miring)

: (Memuat latar belakang masalah, tinjauan pustaka secara ringkas, masalah penelitian dan tujuan penelitian)

: Sesuai dengan kebutuhan (tanpa numbering)

: (Berisi simpulan dan saran)

: (Berisi pustaka yang dirujuk dalam uraian naskah) 
5. Referensi sumber dalam teks artikel ditulis dengan menggunakan side note, contoh: (Jalalluddin, 1991:79); (Taufik, 2005;350); (Hamid dan Madjid, 2011:43). Sementara penulisan daftar pustaka disusun dengan ketentuan. Nama Pengarang. Tahun Terbit. Judul (dicetak miring). Kota Terbit: Nama Penerbit. Contoh: Koentjaraningrat. 2010. Manusia dan Kebudayaan Di Indonesia. Jakarta: Djambatan.

Daftar pustaka hanya memuat pustaka/sumber yang dirujuk dalam uraian dan disusun menurut abjad, tanpa nomor urut.

6. Naskah yang dimuat akan disunting kembali oleh redaksi tanpa mengubah isinya.

7. Naskah yang ditolak (tidak bisa dimuat) akan dikirim kembali ke penulis dengan pemberitahuan tertulis dari redaksi atau alamat email.

8. Penulis yang naskahnya dimuat akan mendapatkan 1 (satu) majalah nomor yang bersangkutan.

9. Contact Person: Treny (085357344704) dan Mainur (081373165553). 